\title{
EVALUASI PENYUSUNAN ANGGARAN DAN KINERJA KEUANGAN DI KECAMATAN SONDER KABUPATEN MINAHASA
}

\author{
Chelsea Pangalila ${ }^{1}$, Inggriani Elim² ${ }^{2}$ Stanley Kho Walandouw ${ }^{3}$ \\ 1,2,3 Jurusan Akuntansi, Fakultas Ekonomi dan Bisnis,Universitas Sam Ratulangi, J1. Kampus Bahu, Manado, \\ 95115, Indonesia \\ E-mail : Pangalila.chelsea@yahoo.co.id
}

\begin{abstract}
Budget is a blueprint of the existence of a State and is a future directive. The Local Government Budgeting Process should be a benchmark for achieving the expected performance, so that regional budget planning should be able to clearly describe the performance objectives. With the preparation of a good budget, can be easily obtained information in decision-making. Local governments are responsible for the management of local finances. In the implementation of regional financial management, the regional head holds the general power obliged to carry out in accordance with the Rules that have been determined. In order for the implementation of local financial management carried out in an orderly and obedient to the applicable legislation. The purpose of this research is to know how the process of budget preparation and how the financial performance in Sonder District of Minahasa regency. Data collection method used is qualitative descriptive analysis that is by describing the preparation of budget and financial performance of local government in subdistrict sonder. The results of the research show that the process of Budgeting Process in Sonder District starts from the preparation of the Local Government Work Plan (RKPD), KUA / PPAS up to the Working Budget Plan of Local Government Work Unit (RKA-SKPD) Then presented to the Implementation Document of the Budget of Work Unit of Regional Region (DPA-SKPD). Budgeting and financial performance of local government in Kecamatan Sonder is quite effective. where the budgeting is done using the Planning, Programming, and Budgeting System (PBBS) approach, and the financial performance in the preparation of the budget goes well despite the delay but the implementation is still good and under control. This can be seen from how the process of preparing the budget and strategic plans that are set in the long term.
\end{abstract}

Keywords: Budget Drafting Process, Financial Performance

\section{PENDAHULUAN}

Anggaran Pendapatan dan Belanja Daerah (APBD) adalah Rancangan Keuangan Pemerintah Daerah yang dibahas dan setujui bersama oleh Pemerintah Daerah dan DPRD yang telah ditetapkan dengan Peraturan Daerah, merupakan hak dan kewajiban yang diberikan kepada Kepala Daerah untuk mengelola keuangan daerah yang merupakan sebuah bentuk pertanggungjawaban. Dalam rangka mewujudkan pertanggungjawaban Keuangan Pemerintah Daerah yang akuntabel dan transparan maka dibutuhkan sebuah Sistem Akuntansi Keuangan Daerah yang mampu mewujudkan sebuah laporan keuangan yang memadai serta dalam rangka tertib dalam pengelolaan keuangan daerah dan pelaksanaan disiplin anggaran arus beban APBD Kabupaten Minahasa. Syarifuddin (2013: 30) menyatakan bahwa penyusunan anggaran diharapkan akan meningkatkan kinerja para manajer,dimana ketika suatu tujuan dirancang dan secara partisipasi disetujui, maka karyawan akan menginternalisasikan tujuan yang ditetapkan, dan memiliki rasa tangung jawab pribadi untuk mencapainya karena mereka ikut terlibat dalam penyusunan anggaran tersebut. 
Produk hukum terbaru yang menjadi acuan pemerintah dalam menjalankan aktivitas pengelolaan keuangannya yaitu Peraturan Menteri Dalam Negeri Nomor 13 Tahun 2006 tentang Pedoman Pengelolaan Keuangan Daerah dan Peraturan Menteri Dalam Negeri Nomor 59 tahun 2007 tentang Perubahan atas Peraturan Menteri Dalam Negeri Nomor 13 Tahun 2006 Tentang Pedoman Pengelolaan Keuangan Daerah. Proses penyusunan anggaran merupakan kegiatan penting yang melibatkan berbagai pihak, baik manajer tingkat atas maupun manajer tingkat bawah dimana masing-masing pihak memainkan peran dalam mempersiapkan dan mengevaluasi berbagai alternative dan tujuan anggaran.

Pada kenyataannya, saat ini proses penyusunan di Kecamatan Sonder belum berjalan tepat waktu, dikarenakan terlambatnya pemasukan rencana kegiatan pemerintah yang dari desa dan terlambatnya penyampaian dari Kabupaten ke Kecamatan sedangkan batas waktu pelaporan yang diberikan hanya singkat, sehingga Penyusunan mengalami keterlambatan penyampaian padahal untuk selanjutnya akan dibuat penjabaran APBD. Berdasarkan latar belakang masalah yang telah diuraikan, maka penulis merumuskan masalah yang akan di bahas yaitu Bagaimana Penyusunan Anggaran Satuan Kerja Perangkat Daerah di Kantor Camat Sonder?, dan Bagaimana Kinerja Keuangan Aparatur Pemerintah Daerah Di Kantor Camat Sonder ? Tujuan penelitian ini adalah Untuk mengetahui bagaimana Penyusunan Anggaran di Kantor Camat Sonder ? dan Untuk mengetahui bagaimana Kinerja Keuangan Aparatur Pemerintah Daerah Kecamatan Sonder?

\section{TINJAUAN PUSTAKA}

\subsection{Konsep Akuntansi}

Halim Kusufi (2012: 36) menyatakan bahwa akuntansi sebagai suatu proses pengidentifikasian, pengukuran, pencatatan, dan pelaporan transaksi ekonomi (keuangan) dari suatu organisasi/entitas yang dijadikan sebagai informasi dalam rangka pengambilan keputusan ekonomi oleh pihak-pihak yang memerlukan.

\subsection{Akuntansi Sektor Publik}

Renyowijoyo (2013: 1) menyatakan dalam waktu yang relative singkat akuntansi sektor publik telah mengalami perkembangan yang sangat pesat. Saat ini telah terdapat perhatian yang lebih besar terhadap praktek akuntansi yang dilakukan oleh lembaga-lembaga pemerintah, perusahaan milik Negara/daerah, dan berbagai organisasi publik lainnya di bandingkan dengan pada masa-masa sebelumnya.

\subsection{Anggaran}

Anggaran adalah rencana kerja organisasi dimasa mendatang yang diwujudkan dalam bentuk kuantitatif, formal, dan sistematis (Tika Sari,2013). Proses penyiapan anggaran disebut penganggaran Anggaran juga harus disusun menggunakan suatu urutan tertentu, bukan acak-acakan. Penyusunan anggaran yang baik adalah untuk mempermudah anggota organisasi memahami target yang harus dicapai oleh perusahaan dan untuk melihat hubungan antara satu bagian rencana kerja dengan bagian lainnya.

\subsection{Tujuan dan Manfaat Anggaran}

Tujuan utama dalam penyusunan anggaran dalam organisasi adalah memberikan pedoman kerja yang lengkap dalam menjalankan aktivitas organisasi demi tercapainya hasil yang diharapkan oleh organisasi.

\subsection{Jenis Anggaran}

Walaupun anggaran yang harus disusun organisasi terdiri dari berbagai jenis anggaran, tetapi dasarnya anggaran pada organisasi dapat dikategorikan ke dalam beberapa kelompok anggaran, yaitu :

1. Anggaran operasional

a. Anggaran pendapatan 
Anggaran pendapatan adalah rencana yang dibuat organisasi untuk memperoleh pendapatan pada kurun waktu tertentu. Anggaran pendapatan dapat disusun berdasarkan jenis produk, wilayah pemasaran, kelompok konsumen, atau kelompok wiraniaga.

b. Anggaran biaya

Anggaran biaya merupakan rencana biaya yang akan dikeluarkan organisasi untuk memperoleh pendapatan yang direncanakan. Anggaran biaya biasanya disusun berdasarkan jenis biaya yang dikeluarkan.

c. Anggaran laba

Anggaran laba adalah besarnya laba yang ingin diperoleh organisasi di adalam suatu periode tertentu di masa mendatang. Anggaran laba merupakan gabungan dari anggaran pendapatan dan anggaran biaya.

2. Anggaran Keuangan

Anggaran keuangan mencakup jenis anggaran, yaitu :

a. Anggaran Investasi

Rencana organisasi untuk membeli barang-barang modal atau barang-barang yang dapat digunakan untuk menghasilkan produk organisasi di masa mendatang dalam jangka panjang.

b. Anggaran Kas

Rencana aktivitas penerimaan dan pengeluaran kas organisasi di dalam suatu periode tertentu, beserta penjelasan tentang sumber-sumber penerimaan dan pengeluaran kas tersebut.

c. Proyeksi Neraca

Kondisi keuangan yang diinginkan organisasi di dalam suatu periode tertentu di masa mendatang. Proyeksi neraca mencakup jumlah harta ingin dimiliki organisasi kewajiban-kewajiban yang harus diselesaikan organisasi di masa akan datang.

\subsection{Anggaran Sektor Publik}

Anggaran merupakan pernyataan mengenai estimasi kinerja yang hendak dicapai selama periode waktu tertentu yang dinyatakan dalam ukuran finansial sedangkan penganggaran adalah proses atau metode untuk mempersiapakan suatu anggaran. Renyowijoyo (2013: 52) menyatakan bahwa penganggaran sektor publik merupakan tahapan yang cukup rumit dan mengandung nuansa politik yang tinggi.

Jenis anggaran sektor publik:

a. Anggaran Negara dan Daerah APBN/APBD (Budget of state)

b. Rencana kegiatan dan anggaran perusahaan (RKAP), yaitu anggaran usaha setiap BUMN/BUMD serta badan hukum publik atau gabungan publik swasta.

Mahsun, dkk (2012: 56) menyatakan bahwa fungsi dari anggaran sektor publik adalah :

1. Anggaran sebagai alat perencanaan (Planning Tol)

2. Anggaran sebagai alat pengendalian (Control Tol)

3. Anggaran sebagai alat koordinasi dan alat Komunikasi intern (Coordination and Communication)

4. Anggaran sebagai alat kebijakan fiscal (fiscal Tol)

5. Anggaran sebagai alat penilaian kerja (Performance Measurement Tool)

6. Anggaran sebagai alat instrument politik (political Tol)

7. Anggaran sebagai alat pemotivasi

8. Anggaran sebagai alat untuk menciptakan ruang publik

\subsection{Proses Penyusunan Anggaran}

Proses penyusunan anggaran yang berhasil dapat menjadikan setiap manajer dalam organisasi perusahaan memiliki persepsi yang jelas mengenai peran mereka masing-masing dalam mencapai sasaran anggaran. 
Renyowijoyo (2013: 69) menyatakan bahwa tahap penyusunan anggaran adalah sebagai berikut :

1. Penetapan sasaran oleh manajer atas.

2. Pengajuan usulan aktivitas dan taksiran sumber daya yang dipelukan untuk melaksanakan aktivitas tersebut oleh manajer bawah.

3. Review oleh manajer atas terhadap usulan anggaran yag diajukan oleh manajer bawah

4. Persetujuan oleh manajer atas terhadap usulan anggaran yang diajukan oleh manajer bawah.

Ada 4 (empat) pendekatan penyusunan anggaran menurut Nordiawan dan Hertianti (2012 : 25),yaitu :

1. Pendekatan Tradisional

Pendekatan ini menggunakan asumsi bahwa setiap jenis biaya akan dinaikan jumlahnya pada tingkat kenaikan yang relative sama tanpa memperhatikan kebutuhan yang seharusnya, cara membuat anggaran dengan menggunakan pendekatan ini adalah mengidentifikasi seluruh jenis belanja yang akan dilaksanakan oleh organisasi. Jadi, ciri-ciri pendekatan tradisional adalah disusun berdasarkan daftar belanja yang akan dilakukan organisasi sehingga bentuknya terlihat seperti daftar pos-pos belanja suatu organisasi, dan umumnya bersifat incremental yaitu penentuan setiap jenis dan jumlah biaya yang ada pada anggaran dari suatu periode anggaran tertentu didasarkan pada presentase kenaikan tertentu dari tiap jenis dan jumlah biaya yang sama dengan tahun anggaran sebulumnya.

2. Pendekatan Kinerja

Pendekatan kinerja diperkenalkan untuk mengatasi berbagai kelemahan yang terdapat dalam pendekatan anggaran tradisional, khusunya kelemahan yang disebabkan oleh tidak adanya tolak ukur yang dapat digunakan untuk mengukur kinerja dalam pencapaian tujuan dan sasaran pelayanan publik. Dengan demikian pendekatan kinerja, organisasi akan lebih memperihatinkan aspek pencapaian kinerja di banding sekedar penghematan biaya semata. Karakteristik utama dari pendekatan ini adalah mengelompokkan anggaran berdasarkan program atau aktivitas, setiap program dilengkapi dengan indikator kinerja yang menjadi tolak ukur keberhasilan, dan pada tingkat yang lebih maju pendekatan ini didikan dengan diterapkannya unit costing untuk setiap aktivitas.

3. Pendekatan Sistem Perencanaan, Program, dan Anggaran Terpadu (Planing,Programming, and Budgeting System-PPBS)

PBBS merupakan upaya sistematis yang memperlihatkan integrasi dari perencanaan, pembuatan program, dan penganggaran. Karakteristik PBBS adalah pendekatan ini dirumuskan dalam bentuk program atau aktivitas dari visi, misi, dan tujuan yang terdapat dalam dokumen perencanaan. PBBS merupakan satu kesatuan dengan tahap perencanaan, indikator kinerja disusun dan dikembangkan secara integrasi dengan sasaran strategis yang ada di dokumen perencanaan, dan pendekatan ini memperhitungkan kebutuhan biaya dalam jangka menengah sebagai upaya konsistensi dengan sasaran strategis.

4. $\quad$ Pendekatan Anggaran Berbasis Nol (Zero Based Budgeting-ZBB)

Pendekatan pembuatan anggaran ini adalah setiap aktivitas atau program yang telah diadakan ditahun-tahun sebelumnya tidak secara otomatis dapat dilanjutkan. Setiap aktivitas harus dievaluasi setiap tahun untuk menentukan apakah aktivitas itu akan diadakan tahun ini dengan melihat kontribusi yang diberikan kepada tujuan organisasi.

\subsection{Kinerja Keuangan}

Kinerja keuangan merupakan gambaran pencapaian dari suatu perusahaan kinerja keuangan dapat diperoleh dari informasi laporan keuangan. Rudianto (2013: 189) berpendapat bahwa kinerja keuangan adalah hasil prestasi yang telah dicapai oleh manajemen perusahaan dalam menjalankan fungsinya mengelola asset perusahaan secara efektif selama periode tertentu. Kinerja Keuangan adalah suatu analisis yang dilakukan untuk melihat sejauh 
mana perusahaan telah melaksanakan tugas dengan menggunakan aturan - aturan pelaksanaan keuangan secara baik dan benar seperti dalam membuat suatu laporan keuangan yang telah memenuhi standar atau ketentuan dalam SAK (standar akuntansi keuangan) atau GAAP (generally accepted accounting princip ). Menurut pemaparan tersebut dapat ditarik kesimpulan bahwa kinerja keuangan adalah hasil atau prestasi suatu perusahaan yang dicapai dalam suatu periode atau beberapa periode tertentu dalam pengelolaan keuangan perusahaan dengan prestasi perusahaan tersebut dapat menggambarkan kinerja perusahaan.

\subsection{Tahap - Tahap Dalam Menganalisis Kinerja Keuangan}

Irham Fahmi (2012: 3), berpendapat bahwa ada lima tahapan dalam menganalisis kinerja keuangan perusahaan secara umum yaitu :

1. Melakukan review terhadap data laporan keuangan

Review disini dilakukan dengan tujuan agar laporan keuangan yang sudah dibuat tersebut sesuai dengan penerapan kaidah-kaidah yang berlaku umum dalam dunia akuntansi, sehingga dengan demikian hasil laporan keuangan tersebut dapat dipertanggungjawabkan.

2. Melakukan perhitungan

Penerapan metode perhitungan disini adalah disesuaikan dengan kondisi dan permasalahan yang sedang dilakukan sehingga hasil perhitungan tersebut akan memberikan suatu kesimpulan sesuai dengan analisis yang diinginkan.

3. Melakukan Perbandingan terhadap hasil yang telah diperoleh.

Dari hasil hitungan yang sudah diperoleh tersebut kemudian dilakukan perbandingan dengan hasil hitungan dari berbagai perusahan lain. Metode yang paling umum dipergunakan untuk melakukan perbandingan ini ada dua yaitu :

a. Time series Analiysis, yaitu membandingkan secara antarwaktu atau periode, dengan tujuan itu nantinya akan terlihat secara grafik.

b. Cross sectional approach, yaitu melakukan perbandingan terhadap hasil hitungan rasio-rasio yang telah dilakukan antara satu perusahaan dan perusahaan lainnya dalam ruang lingkup yang sejenis yang dilakukan secara bersamaan. Dari Hasil penggunaan kedua metode ini diharapkan nantinya akan dapat dibuat satu kesimpulan yang menyatakan posisi perusahan tersebut berada dalam kondisi sangat baik, baik, sedang/normal, tidak baik, dan sangat tidak baik.

4. Melakukan penafsiran (interprestasi) terhadap berbagai permasalahan yang ditemukan.

Pada tahap ini analisis melihat kinerja keuangan perusahaan adalah setelah dilakukan tahap tersebut selanjutnya dilakukan penafsiran untuk melihat apa-apa saja permasalahan dan kendala-kendala yang dialami perusahan tersebut.

5. Mencari dan memberikan pemecahan masalah (solution) tehadap berbagai permasalahan yang ditemukan.

Pada tahap terakhir ini setelah ditemukan berbagai permasalahan yang dihadapi maka dicarikan solusi guna memberikan suatu input atau masukan agar apa yang menjadi kendala dan hambatan selama ini dapat terselesaikan.

\subsection{Kinerja Aparatur Pemerintah Daerah}

Kinerja aparatur Pemerintah daerah dilihat berdasarkan kemampuan aparat dalam melaksanakan tugas-tugas manajerial yang meliputi perencanaan, investigasi, koordinasi, supervise, dan pengeturan staf, negosiasi dan refresentasi. Santoso (2012: 55) menyatakan bahwa ada beberapa faktor yang diduga menyebabkan kinerja pemerintah daerah diantaranya karena sistem pengelolaan keuangan daerah yang masih lemah dimulai dalam proses perencanaan dan penganggaran APBD, pelaksanaan/penatausahaan APBD, pertanggungjawaban yang berupa pelaporan hasil pelaksanaan APBD dan pengawasan. 


\subsection{Faktor-faktor yang Mempengaruhi Kinerja Aparatur Pemerintah Daerah}

Faktor - faktor yang mempengaruhi kinerja terdiri dari motivasi, kemampuan, pengetahuan, keahlian, pendidikan, pengalaman, pelatihan, minat, sikap, kepribadian, kondisi-kondisi fisik dan kebutuhan fisiologis, kebutuhan sosial dan kebutuhan egoistik. Mahsun (2012: 145) menyatakan bahwa ada beberapa elemen pokok dalam kinerja yaitu :

1. Menetapkan tujuan, sasaran, dan strategi organisasi.

2. Merumuskan indikator dan ukuran kinerja.

3. Mengukur tingkat ketercapaian tujuan dan sasaran-sasaran organisasi.

4. Evaluasi kinerja, penilaian kemajuan organisasi, meningkatkan kualitas pengambilan keputusan dan akuntabilitas. Dengan mengevaluasi kinerja aparat pemerintah daerah maka akan diketahui seberapa besar tingkat partisipasi dalam penyusunan anggaran pemerintah daerah.

\subsection{Penelitian Terdahulu}

1. Dewi (2012), dengan judul : Analisis Proses Penyusunan Anggaran Satuan Kerja Perangkat Daerah (RKA-SKPD) Dinas Pekerjaan Umum Kabupaten Deli Serdang menyatakan bahwa Proses penyusunan anggaran merupakan unsur terpenting dalam pencapaian visi dan misi organisasi karena anggaran dalam organisasi sektor publik merupakan peryataan mengenai estimasi kinerja yang hendak dicapai selama periode waktu tertentu dalam ukuran finansial.

2. Basri (2013) meneliti tentang Analisis Penyusunan Anggaran Dan Laporan Realisasi Anggaran Badan Pemberdayaan Masyarakat dan Pemerintahan Desa Provinsi Sulawesi Utara. Tujuan Untuk Mengetahui proses penyusunan anggaran dan laporan realisasi anggaran pada Badan Pemberdayaan Masyarakat dan Pemerintahan Desa Provisi Sulawesi Utara. Penelitian tersebut menggunakan Metode Deskriptif. Hasil Penelitian menunjukkan bahwa proses penyusunan anggaran Badan Pemberdayaan Masyarakat dan Pemerintahan Desa Kota Kotamobagu telah berdasarkan Peraturan Menteri Dalam Negeri No.13 Tahun 2006 dan No.22 Tahun 2011.Realisasi Anggaran Tahun 2012 sebesar $95,30 \%$.

\section{METODE PENELITIAN}

\subsection{Jenis Penelitian}

Jenis penelitian yang digunakan adalah penelitian deskriptif, Sugiyono (2014: 13) manyatakan bahwa penelitian deskriptif yaitu penelitian yang dilakukan untuk mengetahui variabel mandiri, baik satu variabel atau lebih (independen) tanpa membuat perbandingan, atau menghubungkan dengan variabel lain.

\subsection{Metode Pengumpulan Data}

\subsubsection{Jenis Data}

Dalam penelitian ini peneliti mengunakan data kualitatif yaitu :

Data kualitatif adalah data yang disajikan secara deskriptif atau dalam bentuk uraian.

\subsubsection{Sumber Data}

Data Primer adalah sumber data yang langsung memberikan data kepada pengumpul data (Yaniawati 2014: 141). Sumber primer ini berupa catatan hasil wawancara yang diperoleh melalui wawancara serta observasi lapangan yang dilakukan oleh peneliti

Data Sekunder merupakan sumber yang tidak langsung memberikan data kepada pengumpul data, misalnya lewat orang lain atau lewat dokumen (Yaniawati 2014: 141). Pengumpulan data sekunder dan kajian kepustakaan (literatur), didefinisikan sebagai penelusuran yang dilakukan oleh peneliti terhadap sumber pendukung untuk kepentingan penelitian yang sedang dilakukan. 


\subsection{Metode Analisis}

Sugiyono (2014: 3) menyatakan bahwa Metode dalam penelitian pada dasarnya merupakan cara ilmiah untuk mendapatkan data dengan tujuan tertentu. Untuk menjawab rumusan masalah, maka metode analisis yang digunakan adalah metode analisis deskriptif dengan pendekatan kualitatif. Analisis deskriptif yang digunakan dalam penelitian ini untuk menggambarkan keadaan dari penyusunan anggaran dan kinerja keuangan Pemerintah daerah yang sesuai dengan teori serta membangdingkan dengan praktek dari penyusunan anggaran dan kinerja keuangan aparatur pemerintah daerah yang ada di Kecamatan Sonder.

\section{HASIL PENELITIAN DAN PEMBAHASAN}

\subsection{Hasil Penelitian}

Penyusunan anggaran di Kantor Kecamatan Sonder dimulai dari pengumpulan data dari bidang program/kegiatan yang akan dilaksanakan. Program kegiatan yang disusun setiap bidang didasarkan pada Rencana Strategis (RENSTRA) Kantor Kecamatan Sonder yang memberikan gambaran dan arahan kebijakan serta strategi pembangunan sebagai tolak ukur dan alat bantu dalam melaksanakan tugas dan fungsi Kantor Kecamatan Sonder. Tahapan Penyusunan anggaran satuan kerja pemerintah daerah adalah sebagai berikut.

\section{Rencana Kerja Pembangunan Daerah (RKPD)}

Data dari setiap bidang akan dituangkan dalam Rencana Kerja Kantor Kecamatan Sonder. Rencana Kerja Pembangunan Daerah (RKPD) merupakan penjabaran RPJMD untuk 1 (satu) tahun periode yang akan memuat program dan kegiatan pembangunan yang dilaksanakan oleh pemerintah maupun yang ditempuh dengan mendorong partisipasi masyarakat. Sebagai dokumentasi pemerintah maupun daerah Renja dan RKPD mempunyai kedudukan yang strategis yaitu menjembatani antara perencanaan strategis ke dalam rencana regional dengan memuat kebijakan pembangunan, prioritas pembangunan, rancangan karangka ekonomi daerah dan program kegiatan SKPD sebagai rencana oprasional RKPD yang merupakan pedoman dalam penyusunan kebijakan umum anggaran (KUA) dan prioritas plafon anggaran sementara (PPAS).

\section{KUA dan PPAS}

Kebijakan umum APBD (KUA) adalah sasaran dan kebijakan daerah dalam satu tahun anggaran yang menjadi petunjuk dan ketentuan umum yang disepakati sebagai pedoman penyusunan RAPBD dan RP-APB program dan kegiatan. Program dan Kegiatan yang sumber pembiayaan dari APBD ada 8 Program Strategis yaitu sebagai berikut:

1. Program Pelayanan Administrasi Perkantoran

2. Program Peningkatan Saranan Dan Prasarana Aparatur

3. Program Peningkatan Disiplin Aparatur

4. Program Peningkatan Kapasitas Sumber Daya Aparatur

5. Program Peningkatan Kapasitas Aparatur Pemerintah Desa

6. Program Perencanaan Pembangunan Daerah

7. Program Penanganan Bencana

8. Program Peningkatan Pelayanan Kepada Masyarakat

Prioritas dan Plafon Anggaran Sementara (PPAS) adalah Jumlah rupiah batas tertinggi yang dapat dianggarkan oleh tiap-tiap satuan kerja perangkat daerah, termasuk didalamnya belanja dapat dianggarkan oleh tiap-tiap satuan kerja perangkat daerah, termasuk di dalamnya belanja pegawai. Plafon anggaran yang disepakati oleh Pemerintah Daerah dengan DPRD bersifat sementara dalam arti bahwa plafon anggaran yang bersifat tetap/Prioritas Anggaran (PPA) SKPD. Prioritas Plafon Anggaran (PPA) yang telah ditetapkan selanjutnya dijadikan pedoman dalam penyusunan rencana anggaran SKPD pada masing-masing SKPD. 
3. Rencana Kerja Anggaran Satuan Kerja Perangkat Daerah (RKA-SKPD)

KUA/PPAS yang telah disepakati antara Kepala Daerah tentang Pedoman Penyusunan RKA-SKPD. Dalam surat Edaran Kepala Daerah memuat hal-hal berikut.

1. PPA yang dialokasikan untuk setiap program SKPD berikut rencana pendapatan dan pembiyaan.

2. Sinkronisasi Program dan kegiatan antar SKPD dan Kinerja SKPD berkenaan sesuai standar pelayanan minimal yang ditetapkan.

3. Batas waktu penyampaian RKA-SKPD kepada PPKD.

4. Hal-hal lainnya perlu mendapatkan perhatian dari SKPD terkait dengan Prinsipprinsip peningktan efisiensi, efektivitas, transparansi, dan akuntabilitas penyusunan anggaran dalam rangka pencapaian prestasi kerja.

5. Dokumen sebagai lampiran surat edaran meliputi KUA, PPA, kode rekening APBD, format RKA-SKPD, analisis standar belanja,dan standar satuan harga.

4. Dokumen Pelaksanaan Anggaran Satuan Kerja Perangkat Daerah (DPA-SKPD)

Dalam proses menyusun anggaran Kantor Kecamatan Sonder yang menyusun Rencana Kerja Anggaran Satuan Kerja Perangkat Daerah (RKA-SKPD) yang kemudian diinput kepada Pemerintah Kabupaten untuk menyusun Dokumen Pelaksanaan Anggaran Satuan Kerja Perangkat Daerah (DPA-SKPD). Dokumen Pelaksanaan Anggaran Satuan kerja Perangkat Daerah (DPA-SKPD) marupakan dokumen yang memuat pendapatan, belanja dan pembiayaan yang digunakan sebagai dasar pelaksanaan anggaran oleh pengguna anggaran. Dalam DPA-SKPD Kantor Kecamatan Sonder program Kegiatan sebagai berikut:

1. Program Pelayanan Administrasi Perkantoran

2. Program Peningkatan Sarana Dan Prasarana Aparatur

3. Program Peningkatan Disiplin Aparatur

4. Program Peningkatan Kapasitas Sumber Daya Aparatur

5. Program Peningkatan Kapasitas Aparatur Pemerintah Desa

6. Program Perencanaan Pembangunan Daerah

7. Program Penanganan Bencana

8. Program Peningkatan Pelayanan Kepada Masyarakat

Proses Penyusunan Anggaran di Kecamatan Sonder, dapat dikatakan bahwa secara garis besar menggunakan sistem Perencanaan, program dan anggaran terpadu (Planning, programming, and budgeting system-PPBS). PPBS Merupakan upaya sistematis yang memperhatikan integrasi dari perencanaan, pembuatan program, penganggaran dan di ingkungan SKPD adalah untuk mengahasilkan dokumen rencana kerja dan anggaran. Penyusunan anggaran terpadu dilakukan dengan mengintegrasikan seluruh proses perencanaan dan penganggaran di lingkungan Kementrian dan Lembaga untuk menghasilkan dokumen kerja anggaran dengan klasifikasi anggaran menurut organisasi, fungsi dan jenis belanja. integrasi atau keterpaduan proses perencanaan dan penganggaran dimaksudkan agar tidak terjadi duplikasi dalam penyediaan dana untuk kementrian dan lembaga baik bersifat investasi maupun untuk keperluan biaya oprasional.

\subsection{Pembahasan}

Berdasarkan hasil penelitian yang telah dilakukan Proses Penyusunan Anggaran di Kecamatan Sonder di mulai dari penyusunan Rencana kerja Pemerintah Daerah (RKPD), KUA/PPAS sampai dengan Rencan Kerja Anggaran Satuan kerja Perangkat Daerah (RKASKPD) Kemudian disajikan kedalam Dokumen Pelaksanaan Anggaran Satuan Kerja Perangkat Daerah (DPA-SKPD). dapat dikatakan bahwa secara garis besar proses penyusunan anggaran tersebut menggunakan pendekatan sistem Perencanaan, program, dan anggaran terpadu (planning, programming, and budgeting system-PPBS), Dimana PPBS merupakan teknik penganggaran yang didasarkan pada teori sistem yang berorientasi pada 
output dan tujuan dengan penekanan utamanya adalah alokasi sumber daya berdasarkan analisis ekonomi. Sistem anggaran PPBS tidak mendasarkan pada struktur organisasi tradisional yang terdiri dari divisi-divisi, namun berdasarkan program, yaitu pengelompokan aktivitas untuk mencapai tujuan tertentu. PPBS adalah salah satu model penganggaran yang ditujukan untuk membantu manajemen pemerintah dalam membuat keputusan alokasi sumber daya secara lebih baik. Hal tersebut disebabkan sumber daya yang dimiliki pemerintah terbatas jumlahnya, sementara tuntutan masyarakat tidak terbatas jumlahnya. Pendekatan ini merupakan upaya sistematis yang memperhatikan integrasi dari perencanaan, pembuatan program, penganggaran dan di lingkungan SKPD adalah untuk menghasilkan Dokumen Rencana Kerja dan Anggaran Sektor Publik Proses Penyusunan Anggaran di Kecamatan Sonder dapat dikatakan cukup baik dan telah sesuai dengan Produk hukum terbaru yang menjadi acuan pemerintah dalam menjalankan aktivitas pengelolaan keuangannya yaitu Peraturan Menteri Dalam Negeri Nomor 13 Tahun 2006 tentang Pedoman Pengelolaan Keuangan Daerah.

\section{PENUTUP}

5.1 Kesimpulan

1. Proses Penyusunan Anggaran di kecamatan Sonder di mulai dari penyusunan Rencana kerja Pemerintah Daerah (RKPD), KUA/PPAS sampai dengan Rencan Kerja Anggaran Satuan kerja Perangkat Daerah (RKA-SKPD) Kemudian disajikan kedalam Dokumen Pelaksanaan Anggaran Satuan Kerja Perangkat Daerah (DPA-SKPD). Penyusunan Anggaran menggunakan pendekatan perencanaan, program dan anggaran terpadu. PPBS mensyaratkan organisasi menyusun rencana jangka panjang untuk mewujudkan tujuan organisasi melalui program-program.

2. Kinerja Keuangan dari Aparatur Pemerintah di Kecamatan Sonder dalam proses penyusunan anggaran cukup baik Namun masih ada kegiatan seperti dalam penyusunan RKA-SKPD yang belum dapat dipenuhi semuanya karena keterlambatan penyampaian Laporan Rencana Kegiatan Pemerintah (RKP) yang dari Desa-desa terlambat dimasukan ke Kecamatan dan terlambatnya penyampaian dari Kabupaten ke Kecamatan sedangkan batas waktu yang diberikan hanya singkat.

\subsection{Saran}

1. Dalam Penyusunan Anggaran di Kecamatan Sonder hendaknya dilakukan tepat waktu agar pelaksanaan dan penggunaanya dapat dipertanggung jawabkan.

2. Kinerja Keuangan Aparatur pemerintah yang ada harus ditingkatkan lagi baik agar supaya dalam penyusunan anggaran akan berjalan dengan baik dan tepat waktu penyampaiannya

\section{DAFTAR PUSTAKA}

Fahmi, Irham. 2012. Analisis Laporan Keuangan.Cetakan Ke-2. Bandung: Alfabeta

Kusufi, 2012. Akuntansi Sektor Publik dan Akuntansi keuangan Daerah. Edisi Empat. Erlangga, Jakarta.

Mahsun, Dkk . 2012. Akuntansi Sektor Publik. Yogyakarta : BPFE

Nordiawan, Hertianti. 2012. Teknik Penyusunan Anggaran Sektor Publik, Penerbit BPFE, Yogyakarta.

Peraturan Menteri Dalam Negeri Nomor 13 Tahun 2006 Tentang Pedoman Pengelolaan Keuangan Daerah

Putra dan Rahmawati. 2012. Konsep Akuntansi Keuangan Pemerintah Daerah, Penerbit Kencana, Jakarta. 
Putra, 2013. Pengaruh Penerapan Anggaran Berbasis Kinerja Dan Sistem Informasi Pengelolaan Keuangan Daerah terhadap Kinerja SKPD di Pemerintah Kabupaten Simalungu.

Renyowijoyo, M. 2013. Akuntansi Sektor Publik : Organisasi Non Laba. Edisi ketiga. Mitra Wacana Media.

Rona, 2011, Pengaruh Penerapan Anggaran Berbasis Kinerja Dan Sistem Informasi Pengelolaan Keuangan Daerah Terhadap Kinerja SKPD di Pemerintahan Kota Kotamobagu.

Rudianto, 2012. Penganggaran, Penerbit Erlangga, Jakarta.

Sari, 2013. Evaluasi Penyusunan Anggaran Sebagai Alat Pengendalian Manajemen Pada BLU Prof. Dr. R. D. Kandouw Manado.

Santoso, 2012. Sistem Pengendalian Manajemen : Konsep, Aplikasi dan Pengukuran Kinerja, Penerbit Indeks, Jakarta.

Sugiyono, 2014. Metode Penelitian Kuantitatif dan Kualitatif (R\&D). Cetakan ke-19. Alfabeta CV. Bandung.

Syarifudin, 2013. Penganggaran: Konsep dan Teknik Penyusunan Anggaran, Penerbit Erlangga, Jakarta.

Yaniawati, 2012. Metode Penelitian. Penerbit: PT. Raja Grafindo Persada, Jakarta. 